\title{
Komitmen Pimpinan Pondok Pesantren Sa'adatuddaren Jambi dalam Pengelolaan Program Pendidikan Kesetaraan Paket B
}

\author{
Sulbani, Mukhtar dan Hidayat \\ Pascasarjana Universitas Islam Negeri Sulthan Thaha Saifuddin Jambi \\ E-mail: sulbani17@gmail.com
}

\begin{abstract}
The commitment of a high school principal can lead to the success of the work of educational organizations by improving the quality of education. The leadership commitment of the Sa'adatuddaren Islamic Boarding School in the management of the Package B or Equality Education Program in Pelayangan District, Jambi City was examined using qualitative methods. The purpose of this study was to review the commitment of the leaders of the Sa'adatuddaren Islamic Boarding School in the management of the Package B Equality Education Program. Data collected through observation, interview and documentation techniques. Determination of research subjects using purposive sampling technique. Data analysis techniques were carried out by reducing data, presenting data and drawing conclusions as well as verifying the reliability of the results obtained by the technique of extension of participation, accuracy of observations, data triangulation and advisory consultation. Based on the data obtained, the commitment of the Sa'adatuddaren leadership in the management of the Package B Equality Education Program at the Islamic Boarding School still low action. There is no priority scale for the improvement of the Package B Equality Education Program annually.
\end{abstract}

Keywords: Leader Commitment; Islamic Boarding School; Sa'adatuddaren Jambi.

\begin{abstract}
Abstrak: Komitmen pimpinan pondok pesantren penting dalam meningkatkan mutu pendidikan. Komitmen pimpinan Pondok Pesantren Sa'adatuddaren dalam pengelolaan program pendidikan kesetaraan Paket B Kecamatan Pelayangan Kota Jambi diteliti menggunakan metode kualitatif. Tujuan dari penelitian ini adalah mengkaji komitmen pimpinan Pondok Pesantren Sa'adatuddaren dalam pengelolaan program pendidikan Kesetaraan Paket B Kecamatan Pelayangan Kota Jambi. Pengumpulan data dilakukan dengan teknik observasi, wawancara dan dokumentasi. Penentuan subjek penelitian menggunakan teknik purposive sampling. Teknik analisis data dilakukan dengan reduksi data, penyajian data dan penarikan kesimpulan serta verifikasi keterpercayaan hasil penelitian diperoleh dengan teknik perpanjangan keikutsertaan, ketelitian pengamatan, triangulasi data dan konsultasi pembimbing. Berdasarkan data yang diperoleh bahwa komitmen pimpinan pondok dalam pengelolaan program Pendidikan Kesetaraan Paket B di Pondok Pesantren Sa'adatuddaren Kota Jambi masih rendah karena tidak adanya skala prioritas perbaikan program Pendidikan Kesetaraan Paket B setiap tahunnya.
\end{abstract}

Kata-kata kunci: Komitmen Pimpinan; Pondok Pesantren; Sa'adatuddaren Jambi.

\section{Pendahuluan}

Proses yang terjadi dari sebuah pendidikan hingga terwujudnya tujuan dari pendidikan itu sendiri membutuhkan proses yang tidak singkat. Tujuan pendidikan yang baik akan mendukung tujuan pendidikan nasional yang 
tercantum pada Undang-Undang Republik Indonesia Nomor 20 Tahun 2003 Tentang Sistem Pendidikan Nasional. Pendidikan biasanya beroperasi di bawah sebuah lembaga Negeri maupun Swasta yang memiliki izin menjadi sebuah organisasi. Keberhasilan pendidikan dapat dipengaruhi oleh beberapa aspek yaitu aspek Internal dan Eksternal.

Salah satu organisasi pendidikan yang ikut serta dalam pembangunan pendidikan adalah organisasi pondok pesantren. Organisasi merupakan wadah kerjasama yang terdiri dari orang-orang untuk melaksanakan kegiatan dalam mencapai tujuan yang telah ditetapkan. Organisasi akan optimal dalam mencapai tujuan jika dalam organisasi dilakukan pengelolaan dengan baik. Tugas pimpinan pondok pesantren dalam membuat kebijakan pondok pesantren harus memiliki data dan catatan yang berkaitan dengan komponen-komponen penyelenggaraan pendidikan. Secara umum komponen pondok pesantren terdiri dari kelembagaan, ketenagaan, administrasi, kurikulum, santri, sarana dan prasarana serta situasi umum di pondok pesantren. Untuk menjamin terlaksananya tugas pendidikan secara baik hendaklah terlebih dahulu dipersiapkan manajemen mutu, elastis, dinamis, dan kondusif yang memungkinkan bagi pencapaian tujuan tersebut. Hal ini berarti bahwa pihak manajerial pondok pesantren dituntut agar dapat menjalankan manajemen mutu dengan cara yang paling baik sesuai dengan keadaan dan situasi lingkungan.

Keberhasilan organisasi tidak dapat dilepaskan dari keberhasilan pemimpin, maka untuk melihat lebih jauh aspek-aspek keberhasilan organisasi dapat dibaca kembali uraian tentang kriteria keberhaslan kepemimpinan. Tetapi bagaimanapun bahwa tingkat perubahan di dalam keberhasilan organisasi dan tingkat perubahan pemeliharaan organisasi merupakan dua indikator yang dapat dipakai untuk melakukan evalusi keberhasilan suatu organisasi. Pimpinan pondok pesantren harus mampu menciptakan suasana kerja yang sehat seperti memupuk dan memelihara kesediaan bekerja sama didalam kelompok demi tercapainya tujuan bersama, menanamkan dan memupuk perasaan anggota masing-masing bahwa mereka termasuk dalam kelompok dapat dibentuk melalui penghargaan terhadap usaha-usahanya dan sifat yang ramah tamah.

Orang-orang yang duduk pada posisi pimpinan pondok pesantren yang benarbenar piawai dalam menjalankan tugas pokok dan fungsinya untuk mencapai tujuan organisasi secara efektif, efisien, dan dengan akuntabilitas tertentu. Mereka harus memiliki etos kerja tinggi, bermartabat, dan mampu memberdayakan seluruh sumber daya yang tersedia ${ }^{1}$. Pemimpin masa depan harus diperkenalkan dengan konsep: (1) kecakapan untuk melihat organisasi melalui beberapa lensa yang berbeda-beda, (2) fleksibel dalam pemikiran, (3) menganjurkan fleksibel dalam tindakan, (4) kecakapan memainkan peran yang perlu dalam situasi, tanpa mengorbankan nilai-nilai dasar ${ }^{2}$. Semua langkah-langkah yang dilakukan pimpinan pondok pesantren ini bisa diistilahkan pemberdayaaan. Istilah 'pemberdayaan' sering digunakan dalam konteks regenerasi berbasis komunitas di mana keterlibatan masyarakat lokal dalam proses regenerasi dipandang sebagai 'memberdayakan'. Umumnya, ini dipandang sebagai menstabilkan kekuasaan

${ }^{1}$ Sudarwan Danim, Kinerja Staf dan Organisasi (Bandung: Pustaka Setia, 2008), hlm. 20.

Eka Prihatin, Teori Administrasi Pendidikan (Bandung: Alfabeta, 2011), hlm. 119. 
antara sektor negara dan masyarakat dan sektor sukarela, dan terkait dengan niat mempromosikan komunitas yang dipimpin perubahan ${ }^{3}$.

Pemimpin pondok pesantren harus memiliki komitmen pada lembaga yang dipimpinnya. Indikator komitmen pimpinan pondok pesantren adalah 1) adanya indentifikasi kebutuhan dan keinginan pimpinan pondok pesantren, 2) keterlibatan pimpinan pondok pesantren dalam aktivitas-aktivitas kerja organisasi dan 3) loyalitas pimpinan pondok pesantren dalam mempertahankan kerjanya dalam organisasi. Komitmen-komitmen yang dicetuskan oleh pemimpin akan diharapkan dapat meningkatkan mutu pesantren. Seperti yang terdapat di Pondok Pesantren Sa'adatuddaren Kota Jambi, pimpinan pondok tersebut mengeluarkan komitmen Program Paket B.

Berdasarkan grand tour di Pondok Pesantren Sa'adatuddaren Kota Jambi ada 205 orang santri, menemukan permasalahan yaitu; 1) belum adanya indentifikasi kebutuhan program pendidikan kesetaraan Paket B, sebab sarana belajar masih terbatas dan ini menghambat kegiatan belajar santri. Sarana belajar sebagai media yang digunakan untuk belajar membawa berbagai hambatan antara lain: a) terbatasnya jumlah buku yang dapat menambah wawasan warga belajar; dan b) kurang dimanfaatkannya sarana belajar atau yang tersedia. Kemudian pihak pondk kesulitan menyediakan guru berkualifikasi pendidikan umum seperti bahasa inggris, IPA, IPS dan Matematika masih terbatas dan ini bisa menghambat kualitas pengelenggaraan paket B yang $\operatorname{ada}^{4}$. , 2) keterlibatan pimpinan pondok pesantren dalam aktivitas-aktivitas kerja program pendidikan kesetaraan Paket B minim sekali dan selama ini masih banyak didelegasikan kepada bawahan yang notabene belum terampil pengelolaan program ini $^{5}$ dan 3) loyalitas pimpinan pondok pesantren dalam mempertahankan kerjanya dalam program pendidikan kesetaraan Paket B masih lemah dan ini bisa dilihat dengan tidak adanya usaha memperbaikan sistem program yang ada dan pendanaan yang tidak diprioritaskan pada perbaikan sistem tersebut. ${ }^{6}$

Penelitian ini menggunakan pendekatan kualitatif untuk menguraikan, menggambarkan, menggali dan mendeskripsikan manajemen pondok pesantren tersebut, pendekatan kualitatif yang dimaksud adalah bahwa terlebih dahulu peneliti mencari literatur atau teori yang berkaitan dengan penelitian, kemudian teori tersebut dibandingkan dengan kondisi lapangan penelitian ${ }^{7}$. Situasi sosial dalam penelitian ini yaitu dapat mengamati secara mendalam aktivitas (activity) orang-orang (actor) yang ada pada tempat (place) tertentu. Situasi penelitian ini adalah Pondok Pesantren Sa'adatuddaren Kota Jambi dengan alasan terdapatnya program kesetaraan Paket B di Kecamatan Pelayangan Kota Jambi. Sumber informasi dalam penelitian ini yaitu pimpinan dan wakil pondok pesantren, serta guru yang dipilih menggunakan purposive sampling ${ }^{8}$.

\footnotetext{
${ }^{3}$ Adamson, Dave and Richard Bromiley, Community Empowerment in Practice (The Homestead 40 Water End York: Joseph Rowntree Foundation, 2008), hlm. 11.

${ }^{4}$ Observasi, 18 Juli 2016

5Wawancara, 21 Juli 2016

${ }^{6}$ Wawancara, 21 Juli 2016

${ }^{7}$ Sugiyono, Metode Penelitian Pendidikan: Pendekatan Kuantitatif, Kualitatif dan $R \& D$ (Bandung: Alfabeta, 2007), hlm. 14.

${ }^{8}$ Sutrisno Hadi, Metodologi Riset (Yogyakarta: Pustaka Pelajar, 2015), hlm. 112.
} 
Jenis data dalam penelitian ini yaitu data primer dan sekunder, dimana data primer ini diperoleh langsung di lapangan pada waktu penelitian sedang berlangsung ${ }^{9}$. Data sekunder adalah yang diperoleh secara tidak langsung oleh peneliti, tetapi telah berjenjang melalui sumber tangan kedua ketiga ${ }^{10}$. Sumber data terdiri atas jenis-jenis informasi yang diperoleh peneliti dari subjek penelitiannya dan dijadikan sebagai responden atau informan, yang menjadi responden adalah pimpinan pondok pesantren, informannya adalah guru-guru ${ }^{11}$. Teknik pengumpulan data pada penelitian ini yaitu observasi ${ }^{12}$, wawancara ${ }^{13}$, dan dokumentasi.

Data yang diperoleh dianalisis menggunakan beberapa teknik analisis data. Analisis data yang digunakan dalam penelitian ini adalah model analisis data mengalir, yang dilakukan sepanjang kegiatan penelitian (during data collection), dan kegiatan yang paling inti mencakup menyederhanaan data (data reduction), penyajian data (data display) serta menarik kesimpulan (making conclusion), ${ }^{14}$ seperti pada Gambar 1. Adapun tingkat kepercayaan data (trustworthiness) dalam penelitian dilakukan suatu teknik pemeriksaan data antara lain; melakukan perpanjangan keikutsertaan, ketekunan pengamatan, triangulasi dan diskusi sejawat ${ }^{15}$.

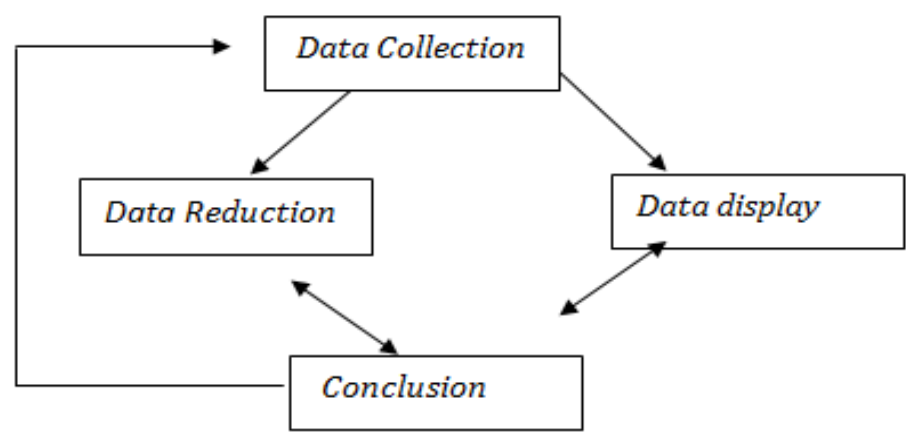

Gambar 1. Analisis Data Model Interaktif (Interaktif Model of Data Analysis)

\section{Komitmen Pimpinan Pondok Pesantren}

Komitmen adalah sikap loyal pekerja pada organisasinya dan suatu proses terus menerus di mana pekerja tersebut berpartisipasi untuk memperbaiki dan keberhasilan organisasi ${ }^{16}$ Komitmen merupakan kata yang mudah diucapkan tetapi sangat sulit diwujudkan. Komitmen adalah sebuah janji yang diungkapkan,

${ }^{9}$ Mukhtar, Op. Cit., hlm. 100.

${ }^{10}$ Mukhtar, Op. Cit., hlm. 100.

11Mukhtar, Op. Cit., hlm. 107.

12Sugiyono, Op. Cit., hlm. 310-317.

${ }^{13}$ Suharsimi Arikunto, op. cit.., hlm. 155.

${ }^{14}$ Matthew B. Miles dan Michael A. Huberman, Analisis Data Kualitatif: Buku Sumber Tentang Metode-Metode Baru Terj. Tjetjep Rohedi Rohidi, (Jakarta: UI Press, 2007), hlm. 16-20. hlm. 175 .

${ }^{15}$ Lexy J. Moleong, Metodologi Penelitian Kualitatif (Bandung: Remaja Rosdakarya, 2013),

16Hilmi, op. cit., hlm. 112. 
namun menetapi janji merupakan sebuah langkah untuk meraih kepercayaan ${ }^{17}$. Dalam organizational commitment, pekerja mengenal atau mengidentifikasi dengan organisasi tertentu dan tujuannya dan mengharapkan tetap menjadi anggota. Terdapat tiga dimensi komitmen organisasional Affective commitment, Continuance commitment, dan Normative commitment ${ }^{18}$.

Pimpinan pondok pesantren memerlukan komitmen dalam memimpin lembaganya. Sukses tidaknya suatu kepemimpinan tidak hanya dipengaruhi kemampuan atau sifat-sifat yang ada pada seseorang, justru yang lebih dominan dipengaruhi oleh sifat dan ciri kelompok yang dipimpinnya, sehingga memerlukan gaya dan model kepemimpinan yang berbeda dan beragam. Faktor-faktor yang mempengaruhi bentuk kepemimpinan seseorang seperti tingkat pendidikan merupakan suatu fenomena yang sangat berarti, sebab rendahnya tingkat pendidikan berarti rendahnya penguasaan kompetensi kepemimpinannya. Nurdi menjelaskan bahwa betapa mahalnya proses memilih pemimpin. Apakah memang sebesar dan semahal itu biaya yang harus kita keluarkan untuk memilih seorang pemimpin? Semua sumber daya kita terkuras untuk memilih seorang pemimpin, yang ternyata belum tentu juga kebaikannya untuk orang banyak ${ }^{19}$.

Pimpinan pondok pesantren yang berkomitmen dan tidak bisa dilihat dari perilakunya sehari-hari dalam mengelola lembaganya. Perilaku kepemimpinan konsiderasi mengandung ciri-ciri sebagai berikut: pimpinan dalam pelaksanaan tugasnya memperhatikan kebutuhan bawahan; pimpinan berusahan menciptakan suasana saling percaya antar bawahan dengan pimpinan dan bawahan dengan bawahan; pimpinan menaruh simpati terhadap bawahan sebagai bagian dari organisasi; pimpina memperhatikan sisi persahabatan dengan bawahan; dan pimpinan lebih mengutamakan pengarahan diri, mendisiplin diri, mengontrol $\operatorname{diri}^{20}$.

Kepemimpinan merupakan sebuah kemampuan yang perlu dimiliki oleh seorang pemimpin dalam menggerakkan seluruh sumber daya organisasi terutama sumber daya manusianya untuk melakukan apa yang diharapkan. Kemampuan inilah yang akan menentukan bahwa seorang pemimpin tersebut baik tidaknya ${ }^{21}$. Perubahan dapat menyebabkan pergolakan besar dalam dinamika kelompok tim kepemimpinan senior dan arah di mana organisasi bergerak. Namun, jika rencana tersebut adalah produk dari tim kepemimpinan seluruh, ia memiliki kesempatan yang lebih baik untuk bertahan transisi kepemimpinan. Rencananya perlu dimiliki oleh tim kepemimpinan, tidak tergantung pada seorang pemimpin tunggal. Mendapatkan penerimaan dan masukan untuk rencana dari anggota baru dari tim kepemimpinan senior sangat penting untuk keberhasilan rencana ini ${ }^{22}$.

${ }^{17}$ Abd. Kadim Masaong, Supervisi Pembelajaran dan Pengembangan Kapasitas Guru: Memberdayakan Pengawas sebagai Gurunya Guru (Bandung: Alfabeta, 2012), hlm. 199.

18Wibowo Perilaku dalam Organisasi (Jakarta: RajaGrafindo, 2013), hlm. 57.

${ }^{19}$ Herry Nurdi Living Islam (Jakarta: Lingkar Pena Kreativa, 2011), hlm. 208.

${ }^{20}$ Minnah El Widdah, dkk., Kepemimpinan Berbasis Nilai dan Pengembangan Mutu Madrasah (Bandung: Alfabeta, 2012), hlm. 48.

${ }^{21}$ Kasful Anwar US., Kepemimpinan Pesantren (Jambi Timur: Sulthan Thaha Press, 2011), hlm. 16.

22Wells, Denise Lindsey, Strategic Management for Senior Leaders: A Handbook for Implementation (Arlington, Virginia: Department of the Navy Total Quality Leadership Office), hlm. 58. 
Pelaksanaan peran dan fungsi kyai sebagai manajer harus memiliki strategi yang tepat guna memberdayakan tenaga kependidikan melalui kerjasama atau kooperatif, memberi kesempatan kepada para tenaga kependidikan untuk meningkatkan profesinya, dan mendorong keterlibatan seluruh tenaga kependidikan dalam berbagai kegiatan yang menunjang program kerja pesantren. Komitmen utama dari pimpinan pondok pesantren adalah keteladanan. Menurut Antonio, dikutup Qomar ${ }^{23}$, teladan kepemimpinan itu sesungguhnya terdapat pada diri Rasulullah, karena ia adalah pemimpin yang holistic, accepted dan proven. Holistic (menyeluruh) karena beliau adalah pemimpin yang mampu dalam mengembangkan leadership dalam berbagai bidang, di antaranya, self development, bisnis dan kewirausahaan dan lain-lain. Kepemimpinan accepted (diterima) karena diakui lebih dari 1.3 milyar manusia. Kepemimpinan proven (terbukti) karena sudah terbukti sejak lebih dari 15 abad yang lalu hingga hari ini masih relevan untuk diterapkan.

Menurut Spambauer, dikutip Usman, model kepemimpinan kepala untuk memberdayakan tenaga kependidikan sebagai berikut: 1) Melibatkan seluruh guru dan staf tata usaha (mereka) dalam pengambilan keputusan, 2) Bertanya kepada mereka bagaimana pendapat mereka agar pondok pesantren lebih maju, 3) Saling bertukar informasi manajemen sedapat mungkin untuk meningkatkan komitmen mereka, 4) Bertanya kepada mereka sistem dan prosedur yang mana yang tepat disampaikan kepada pelanggan eksternal pondok pesantren untuk meningkatkan mutu pondok pesantren, 5) Memahami bahwa manajemen yang bersifat dari atas bahwa tidak cocok dalam mendorong peningkatan profesionalsme guru, 6) Meremajakan pertumbuhan profesional, awalnya tanggung jawab dan kontrol dari pimpinan pondok pesantren menjadi langsung dari mereka, 7) Menerapkan komunikasi sistematis dan terus-menerus antarwarga pondok pesantren, 8) Mengembangkan kemampuan berkonflik, pemecahan masalah dan negosiasi, serta menunjukkan toleransi yang besar terhadap konflik, 9) Siap membantu tanpa banyak tanya dan tanpa menjadi rendah diri, 10) Menyiapkan pendidikan dengan konsep mutu, 11) Model yang ditunjukkan adalah karakteristik kepribadian yang diharapkan oleh warga pondok pesantren dan luar pondok pesantren, 12) Belajar lebih seperti pelatih dan tidak sedikitpun seperti bos, 13) Memberikan otonomi dan mengizinkan untuk mengambil risiko selama terbuka dan terarah dan 14) Menyeimbangkan dengan baik antara jaminan mutu untuk pelanggan eksternal pondok pesantren dengan kesejahteraan yang dibutuhkan pelanggan internal pondok pesantren (guru dan staf atau usaha). ${ }^{24}$

Komitmen pimpinan pondok pesantren yang tinggi bisa mengantar kepada keberhasilan kerja organisasi pendidikan dengan meningkatkan mutu pendidikan. Keberhasilan aplikasi manajemen mutu terpadu di pondok pesantren diukur dari tingkat kepuasan pelanggan baik internal maupun eksternal. pondok pesantren dikatakan berhasil jika mampu memberikan layanan sesuai harapan pelanggan.

Pemimpin yang efektif memiliki indikator sebagai berikut:

a. Gaya eksekutif (executive), yaitu gaya kepemimpinan yang banyak memberikan perhatian pada tugas-tugas pekerjaan dan hubungan kerja.

${ }^{23}$ Mujamil Qomar, Strategi Pendidikan Islam (Jakarta: Erlangga, 2013), hlm. 230.

${ }^{24}$ Husaini Usman, Manajemen (Jakarta: Bumi Aksara, 2008), hlm. 471-472. 
b. Gaya pengembangan (develover), yaitu gaya kepemimpinan yang memberikan perhatian maksimum terhadap hubungan kerja dan perhatian yang minimum terhadap tugas-tugas pekerjaan.

c. Gaya otokrasi yang baik (benevolen autocrat), yaitu gaya kepemimpinan yang memberikan peraian maksimum pada hubungan kerja.

d. Gaya birokrat (bereucrat), yaitu gaya kepemimpinan yang memberikan perhatian minmum terhadap tugas maupun hubungan kerja dalam situasi yang tepat. 25

Menurut Yukl, dikutip Anwar, kebanyak peneliti mengevaluasi efektivitas kepemimpinan dalam kaitannya dengan konsekuensi-konsekuensi dari tindakantindakan pemimpin tersebut bagi para pengikuti dan para stakeholder organisasi lainnya. Ukuran yang biasanya digunakan mengenai efektivitas pemimpin adalah sejauh mana unit organisasi dari pemimpin tersebut melaksanakan tugasnya secara berhasil dan mencapai tujuan-tujuannya. Indikator umum lainya adalah sikap dari para pengikut terhadap pemimin tersebut, seperti rasa suka dan puas. Hormat dan kagum kepada pemimpinnya serta ada tidaknya komitmen yang kuat untuk melaksanakan permintaan-permintaan dari pemimpin.

Pertanyaannya adalah apakah setiap kepala sekolah mampu menciptakan mutu pendidikan yang tinggi. Kepala sekolah dalam hal ini perlu memiliki komitmen yang kuat tentang kejelasan dan evaluasi tugas-tugas guru, merumuskan kegiatan pembelajaran secara kontinu dan evaluatif, serta santri diarahkan ke arah yang motivatif, konstruktif, dan bisa menjadi percontohan. Untuk itu, kepemimpinan kepala sekolah harus mampu menggerakkan semua warga sekolah untuk melaksanakan tugas dan tanggung jawab sesuai dengan tugas dan tanggung jawab yang diberikan. Dalam melaksanakan kepemimpinan di kepala sekolah.

Dalam rangka melakukan peran dan fungsinya sebagai manajer, pimpinan kepala sekolah harus memiliki strategi yang tepat untuk memberdayakan tenaga kependidikan melalui kerja sama atau kooperatif, memberikan kesempatan kepada para tenaga kependidikan untuk meningkatkan profesinya dan mendorong keterlibatkan seluruh tenaga kependidikan dalam berbagai kegiatan yang menunjang program sekolah meliputi:

a. Memberdayakan tenaga kependidikan melalui kerjasama atau kooperatif dimaksudkan bahwa dalam peningkatan profesional tenaga kependidikan di sekolah, kepala sekolah harus mementingkan kerjasama dengan tenaga kependidikan dan pihak lain yang terkait dalam melaksanakan setiap kegiatan.

b. Memberikan kesempatan kepada para tenaga kependidikan untuk meningkatkan profesinya, sebagai manajer kepala sekolah harus meningkatkan profesi secara persuasif dan dari hati ke hati.

c. Mendorong keterlibatan seluruh tenaga kependidikan, dimaksudkan bahwa kepala harus berusaha untuk mendorong keterlibatan semua tenaga kependidikan dalam setiap kegiatan di sekolah (partisipatif) ${ }^{26}$.

Berdasarkan teori di atas dapat diketahui bahwa komitmen pimpinan pondok pesantren adalah sikap loyal pimpinan pondok pesantren pada organisasinya dan

${ }^{25}$ Kasful Anwar US, Op. Cit., hlm. 45.

26E. Mulyasa, Menjadi Kepala Sekolah Profesional, (Bandung: Remaja Rosdakarya, 2006), hlm. 
suatu proses terus menerus di mana pimpinan pondok pesantren tersebut berpartisipasi untuk memperbaiki keberhasilan organisasi. Indikator komitmen pimpinan pondok pesantren adalah 1) adanya indentifikasi kebutuhan dan keinginan pimpinan pondok pesantren, 2) keterlibatan pimpinan pondok pesantren dalam aktivitas-aktivitas kerja organisasi dan 3) loyalitas pimpinan pondok pesantren dalam mempertahankan kerjanya dalam organisasi.

\section{Penelitian Relevan}

Berdasarkan pengkajian terhadap penelitian-penelitian yang telah dilakukan sebelumnya, ada penelitian yang memiliki relevansi dengan penelitian ini, yaitu penelitian:

1. Suharno mengenai Manajemen Pembelajaran Kejar Paket C (Setara SMA) Studi Multi Kasus di PKBM Sidoharjo dan PKBM Slogohimo Kabupaten Wonogiri tahun 2005. Hasil penelitian menyimpulkan bahwa; (1) Karakteristik warga belajar; (a) usia tergolong orang dewasa, (b) pendidikan warga belajar dari Kejar Paket B, SLTP/ MTs , droup out SMA, (c) latar belakang ekonomi orang tua kurang mampu, (d) warga belajar sudah bekerja baik di sektor formal maupun non formal, (2) Manajemen pembelajaran terbagi menjadi tiga tahapan yaitu perencanaan pembelajaran, pelaksanaan pembelajaran dan evaluasi/ penilaian pembelajaran; (a) Perencanaan pembelajaran. Perencanaan pembelajaran Kejar Paket $\mathrm{C}$ yang dilakukan tutor adalah menentukan tujuan pembelajaran, alokasi waktu pembelajaran, bahan pelajaran, kegiatan pembelajaran, metode, media, sumber dan evaluasi, (b) Pelaksanaan pembelajaran. Pelaksanaan pembelajaran pembelajaran Kejar Paket C di PKBM Sidoharjo dan PKBM Slogohimo terdiri dari tiga tahapan yaitu pendahuluan, tahap penyajian inti dan tahap penutup, (c) Evaluasi pembelajaran. Evaluasi yang dilakukan di PKBM Sidoharjo dan PKBM Slogohimo dilakukan setiap akhir pokok bahasan. Hasil evaluasi digunakan sebagai umpan balik kepentingan pembelajaran; (3) Peran tutor PKBM Sidoharjo maupun PKBM Slogohimo sebagai fasilitator belum maksimal, sehingga dalam melaksanakan pembelajara di kelas masih menerapkan pembelajaran konvensional, pendekatan pembelajaran andragogi belum diterapkan sepenuhnya; (4) Peran pengelola dalam mendukung manajemen pembelajaran Kejar Paket C masih sangat minim terutama dalam menyediakan sarana belajar antara lain buku/ modul, media belajar dan tempat belajar. ${ }^{27}$

2. Luluk Yuli Prasetyaningwati mengenai mengenai Analisis Kebijakan Program Pengembangan Diri dalam Upaya Peningkatan Kecakapan Hidup Warga Belajar Paket B di Kota Malang tahun 2009. Berdasarkan temuan penelitian dalam pelaksanaan program pengembangan diri yang dilaksanakan di PKBM dan SKB ternyata terdapat perbedaan di antaranya yaitu pada program kesetaraan SKB hanya ada program Paket B, B, dan paket C. Sedangkan pada PKBM terdapat program kesetaraan usia sekolah yang dilaksanakan mulai Senin sampai Sabtu dan program konvensional yang dilaksanakan hanya $3 \mathrm{~s} / \mathrm{d} 4$ kali pertemuan

${ }^{27}$ Suharno, Manajemen Pembelajaran Kejar Paket C (Setara Sma) Studi Multi Kasus Di PKBM Sidoharjo Dan PKBM Slogohimo Kabupaten Wonogiri, (Tesis), (Surakarta, PPs Univeritas Muhammadiyah Surakarta, 2005). 
dalam satu minggu, dengan dengan mengikuti diklat ketrampilan di SKB. Sedangkan ketrampilan yang didapatkan kadang kurang mempunyai arti bagi mereka karena masih ada yang harus mencari pekerjaan yang tidak sesuai dengan pelatihan yang didapatnya. Maka pihak PKBM sendiri mempunyai rencana akan membuat program yang banyak diminati peserta didik yaitu setir mobil. Rekomendasi ini disampaikan kepada para pembuat kebijakan dan lembaga untuk mengambil langkah-langkah perbaikan pada program pengembangan diri. ${ }^{28}$

3. Rajo Bungsu tahun 2011 dengan tesis berjudul Pelaksanaan Kurikulum Paket B pada Suku Anak Dalam (SAD) di Pondok Pesantren Sa'adatuddaren Kota Jambi Kecamatan Mestong Kota Jambi. Hasil penelitian ini menunjukkan bahwa pelaksanaan Kurikulum Paket B pada SAD di Pondok Pesantren Sa'adatuddaren Kota Jambi belum optimal karena guru masih dihadapkan pada keterbatasan lemahnya kinerja dan wawasan terkait konsep Kurikulum Paket B dan fasilitas yang terbatas. Faktor pendukungnya adalah yaitu pengelola yang selalu memberikan motivasi dan arahan kepada guru agar bekerja dengan baik, sedangkan faktor penghambatnya yaitu terbatasnya wawasan mengajar dan ketersediaan media dan buku-buku pokok/penunjang yang mengacu KTSP kesetaraan, di samping masih belum lengkapnya informasi dari instansi terkait mengenai penyusunan Kurikulum Paket B. Upaya guru meningkatkan pelaksanaan Kurikulum Paket B dengan meningkatkan profesionalitas dan disiplin kerja yang lebih optimal dan mengikuti pelatihan/penataran guru untuk menambah wawasan guru mengajar. ${ }^{29}$

Berdasarkan tiga penelitian di atas, dapat disajikan persamaan dan perbedaan penelitian penulis dengan ketiga:

1. Suharno membahas manajemen pembelajaran kejar paket $\mathrm{C}$, sedangkan penulis membahas komitmen pimpinan dalam pengelolaan program pendidikan kesetaraan Paket B.

2. Luluk Yuli Prasetyaningwati membahas analisis kebijakan program pengembangan diri dalam upaya peningkatan kecakapan hidup warga belajar paket $\mathrm{B}$, fokusnya pada kebijakan pengembangan diri, sedangkan penulis fokus pada komitmen pengelola paket $\mathrm{B}$.

3. Rajo Bungsu membahas Pelaksanaan Kurikulum Paket B, sedangkan penulis tidak sampai membahas kurikulum, hanya membahas aspek manajerial dengan mengkaji komitmen pimpinan lembaga pendidikan.

\section{Komitmen Pimpinan Pondok Pesantren Sa'adatuddaren Kota Jambi dalam Pengelolaan Program Pendidikan Kesetaraan Paket B}

Berdasarkan peroleh informasi bahwa guru dan karyawan memang bekerja sesuai porsinya serta bertanggung jawab atas tugas-tugas yang telah dibebankan

\footnotetext{
${ }^{28}$ Luluk Yuli Prasetyaningwati, Analisis Kebijakan Program Pengembangan Diri dalam Upaya Peningkatan Kecakapan Hidup Warga Belajar Paket B di Kota Malang, (Tesis), (Malang, PPs Univeritas Muhammadiyah Malang, 2009).

${ }^{29}$ Rajo Bungsu. Pelaksanaan Kurikulum Paket A pada Suku Anak Dalam (SAD) di Desa Pelempang Kecamatan Mestong Kabupaten Muaro Jambi. (Tesis). (Jambi: Pascasarjana IAIN STS Jambi, 2011).
} 
kepadanya oleh Pimpinan Pondok Pesantren Sa'adatuddaren Kota Jambi berdasarkan rencana kerja pengelolaan program Pendidikan Kesetaraan Paket B yang telah dibuat dan bersama-sama dengan pegawai, hal ini menunjukkan bahwa perencanaan yang dibuat oleh kepala dapat berjalan dengan baik ${ }^{30}$. Lebih lanjut peneliti juga mengadakan wawancara dengan Pimpinan Pondok Pesantren Sa'adatuddaren Kota Jambi dengan HAM, beliau mengatakan bahwa saya selaku Pimpinan Pondok Pesantren Sa'adatuddaren Kota Jambi ini, menyerahkan sepenuhnya pekerjaan yang menyangkut masalah pengelolaan program Pendidikan Kesetaraan Paket B ini kepada guru, seperti pendataan lembaga, personal guru, sarana prasarana dan laporan bulanan program Pendidikan Kesetaraan Paket B. Sebab kegiatan paket ini sudah menjadi tanggung jawab guru, di samping sebagai tanggung jawab saya selaku Pimpinan Pondok Pesantren Sa'adatuddaren Kota Jambi dalam meningkatkan pengelolaan program Pendidikan Kesetaraan Paket B ${ }^{31}$.

Pimpinan Pondok Pesantren Sa'adatuddaren Kota Jambi sudah mampu menanamkan, memajukan dan meningkatkan nilai mental, moral, fisik, karakteristik dan keteladanan Pimpinan Pondok Pesantren Sa'adatuddaren Kota Jambi melalui sikap, perbuatan dan perilaku termasuk penampilan kerja. Observasi penulis dimana Pimpinan Pondok Pesantren Sa'adatuddaren Kota Jambi menjadi panutan bagi guru pondok. Meskipun Pimpinan Pondok Pesantren Sa'adatuddaren Kota Jambi berusaha memberikan contoh yang terbaik dalam mengelola program Pendidikan Kesetaraan Paket B, namun masih banyak kelemahan dalam disiplin pimpinan seperti bekerja tepat waktu dan selalu ada di tempat ${ }^{32}$. Pimpinan Pondok Pesantren Sa'adatuddaren Kota Jambi mempunyai tugas memimpin, merumuskan kebijakan, menyelenggarakan, mengkoordinasikan dan mengawasi pelaksanaan pengelolaan program Pendidikan Kesetaraan Paket B. Untuk melaksanakan tugas pokok tersebut, Pimpinan Pondok Pesantren Sa'adatuddaren Kota Jambi menyelenggarakan fungsi:

1) Perumusan dan penetapan visi, misi, dan kebijakan teknis di bidang pelayanan pengelolaan program Pendidikan Kesetaraan Paket B.;

2) Pelayanan, bimbingan dan pembinaan pengelolaan program Pendidikan Kesetaraan Paket B.

3) Pelaksanaan kebijakan teknis di bidang pengelolaan administrasi dan informasi pengelolaan program Pendidikan Kesetaraan Paket B.

4) Pengkoordinasian perencanaan, pengendalian, pengawasan, dan evaluasi program pengelolaan program Pendidikan Kesetaraan Paket B.

5) Pelaksanaan hubungan dengan masyarakat dalam rangka pelaksanaan pengelolaan program Pendidikan Kesetaraan Paket B.

Pengembangan pendidikan kesetaraan diarahkan tidak lepas dari landasan empiris. Landasan empiris yang dapat dijadikan acuan adalah lingkungan global lingkungan nasional dan lingkungan lokal. Konsekuensi dari lingkungan global mengharuskan pendidikan kesetaran menerapkan berbagai prinsip dan pendekatan pembelajaran yang sangat mendasar seperti peningkatan mutu secara global sehingga lulusan pendidikan kesetaraan mampu bersaing secara global.

30Wawancara, 25 Agustus 2016

31Wawancara, 25 Agustus 2016

32Observasi, 25 Agustus 2016 
Untuk mewujudkan pendidikan nasional dapat ditempuh melalui tiga jalur yaitu formal, non formal dan informal. Pendidikan kesetaraan adalah program pendidikan nonformal yang menyelenggarakan pendidikan umum yang Setara SD/MI, SMP/MTS dan SMA/MAN yang mencakup program Paket A, Paket B dan Paket C. Program Paket B merupakan satuan dari pendidikan luar sekolah atau dapat di sebut juga sebagai pendidikan non formal. ${ }^{33}$

Sebagai pelayanan pendidikan non formal pada jenjang pendidikan menengah. Keberadaan pendidikan non formal juga dimaksudkan untuk mengatasi persoalan pendidikan di Indonesia, khususnya masalah ketercapaian wajib belajar pendidikan dasar sembilan tahun. Untuk mensukseskan pelaksanaan wajib belajar pendidikan dasar sembilan tahun jalur nonformal diselenggarakan melalui Paket B. Peserta didik program Paket B adalah anggota masyarakat yang memenuhi ketentuan wajib belajar setara SMP/MTs melalui jalur pendidikan nonformal. Persyaratan mengikuti program Paket B adalah lulus SD/MI, lulus program Paket A/sederajat. Tujuan dari program Paket B adalah untuk membekali peserta didik dengan keterampilan fungsional, sikap dan kepribadian profesional yang memfasilitasi proses adaptasi dengan lingkungan kerja. ${ }^{34}$

Pondok Pesantren Sa'adatuddaren Kota Jambi berusaha mengembangkan dan meningkatkan prestasi pengelolaan program Pendidikan Kesetaraan Paket B. Untuk mewujudkan Pimpinan Pondok Pesantren Sa'adatuddaren Kota Jambi telah menentukan tujuan dari kepemimpinannya. Seorang pemimpin pendidikan formal maupun non formal hendaknya mampu untuk memimpin para guru dengan komitmen yang tinggi. Keberhasilan seorang pemimpin akan sangat bergantung pada kualitas kepemimpinannya dalam hal mempengaruhi dan kerja sama dengan peran lain/bawahannya untuk mencapai tujuan. Hal ini menunjukkan bahwa dalam merumuskan tujuan maupun upaya pancapaiannya perlu dilakukan oleh semua anggota kelompok yang bergabung dalam ini warga pondok. Pimpinan Pondok Pesantren Sa'adatuddaren Kota Jambi sebagai leader harus mampu memberikan petunjuk dan pengawasan, meningkatkan kemampuan guru, membuka komunikasi dua arah, dan mendelegasikan tugas.

Kejujuran yang pada hakekatnya menyangkut segi-segi moral, baik dan buruk, dan berbagai segi sopan santun, meliputi pokok-pokok pikiran sebagai berikut : selalu mendasarkan pada ketentuan etis yang berlaku, berpegang teguh pada kebenaran, kuat dalam berpendirian, memiliki ketulusan hati dalam melaksanakan tugas dan tidak menyalahgunakan wewenang yang dibebankan kepadanya, efektif dan efesien dalam menggunakan waktu. Hal ini tampak dalam sosok kepribadian Pimpinan Pondok Pesantren Sa'adatuddaren Kota Jambi.

Dengan sifat-sifat kepribadiannya, pemimpin harus menyesuaikan diri dengan kepribadian kelompok. Kepribadian menyentuh diri manusia, oleh karena itu yang dimaksud dengan kepribadian pemimpin dalam kepemimpinan adalah perilaku dan sikap yang diperlihatkan pemimpin dengan orang yang dipimpinnya.

${ }^{33}$ Abdul Rahmat, "Aktivitas Warga Belajar Paket B Dalam Kegiatan Pembelajaran di PKBM Taman Pendidikan Kelurahan Tapa, Kota Utara", Jurnal Pendidikan Non Formal (JPNF) (Edisi 12 Tahun 2015), hlm. 2.

${ }^{34}$ Rochgiyanti, "Pembelajaran Paket B di PKBM Barito Kota Banjarmasin", Artikel (FKIP Universitas Lambung Mangkurat, Banjarmasin), hlm. 167. 
Bahwa kepribadian manusia termasuk seorang pemimpin cenderung bersifat stabil (permanen) atau berubah, namun tidak berarti sama sekali tidak dapat berubah dan berkembang. Dengan kemauan yang keras seorang pemimpin memiliki peluang yang terbuka untuk mengurangi aspek-aspek kepribadian yang negatif agar tidak merugikan dalam mewujudkan kepemimpinannya.

Tanpa kepemimpinan Pondok Pesantren Sa'adatuddaren Kota Jambi yang sesuai dengan kebutuhkan oganisasi, maka suatu organisasi tidak akan mencapai tujuan yang diharapkan. Padahal kepemimpinannya diposisikan bagi pengembangan kepemimpinan kepala Pimpinan Pondok Pesantren Sa'adatuddaren Kota Jambi dengan pertimbangan:

a. Pimpinan mampu memanfaatkan kepemimpinannya, tidak hanya ketepatan dalam mempergunakan keterampilan dan kemampuan dari masing-masing orang, melainkan juga dalam memperoleh dukungan psikologi untuk perbaikan program.

b. Di dalam suatu usaha perbaikan, orang-orang yang terlibat perlu memperoleh informasi tentang ciri-ciri dari perubahan tersebut. Oleh karena itu, seorang Pimpinan Pondok Pesantren Sa'adatuddaren Kota Jambi harus menaruh perhatian terhadap sejumlah dan arus informasi, sehingga dapat tercipta komunikasi dua arah.

c. Pimpinan Pondok Pesantren Sa'adatuddaren Kota Jambi mampu mempergunakan kepemimpinan dalam membangun saluran komunikasi responsif yang mengarahkan arus informasi ke bawah, paralel, dan ke atas di lingkungan organisasi Pimpinan Pondok Pesantren Sa'adatuddaren Kota Jambi, maupun keluar di lingkungan masyarakat yang lebih luas.

d. Pimpinan Pondok Pesantren Sa'adatuddaren Kota Jambi perlu mengetahui konteks institusional/masalah pembaruan dan mendayagunakan kepemimpinannya dalam mengubah organisasi-organisasi yang dinamis dan organik.

e. Untuk memperoleh dukungan politik demi terciptanya perubahan di lingkungan Pimpinan Pondok Pesantren Sa'adatuddaren Kota Jambi, tetapi badan-badan pemerintah, organisasi guru, orang tua dan kelompok masyarakat harus juga memberikan dukungan ${ }^{35}$.

Pengawasan yang dilakukan Pimpinan Pondok Pesantren Sa'adatuddaren Kota Jambi terhadap komitmen kerja guru secara umum belum dilakukan secara optimal, disebabkan: pertama, kurangnya pengawasan yang dilakukan oleh Pimpinan Pondok Pesantren Sa'adatuddaren Kota Jambi terhadap kerja guru yang melaksanakan pekerjaannya dengan kehendak sendiri tidak mengikuti arahan pimpinan. Kedua, Pimpinan Pondok Pesantren Sa'adatuddaren Kota Jambi tidak memberikan reward dan funisman kepada tenaga kependidikan yang dalam bekerja menyelesaikan administrasi Pondok Pesantren Sa'adatuddaren Kota Jambi. Hal inilah membuat rendahnya minat guru dalam menyelesaikan pekerjaan mereka di pondok. Ketiga, Dalam pengawasan kerja guru tidak dilakukan oleh Pimpinan Pondok Pesantren Sa'adatuddaren Kota Jambi secara rutin sehingga pekerjaan tenaga kependidikan banyak yang menumpuk akibatnya terlambat semua pekerjaan pondok.

35Wahjosumidjo, Op. Cit., hlm. 344-345. 
Komitmen pimpinan pondok yang mengedepankan filosofi bersama adalah usahanya untuk tetap maju membangun lembaga yang dipimpinnya dengan segala sumber daya yang ada sesuai ketentuan yang berlaku. Filosofi ini mengindikasikan bahwa jika ada kesalahan pada dirinya selama memimpin lembaga Pondok Pesantren Sa'adatuddaren Kota Jambi, maka siap dengan pengakuan itu salah, hanya saja filosofi ini sulit dibuktikan dalam studi empirik dan perlu pembuktian yang panjang untuk kebenarannya.

Mengenai komitmen kerja Pimpinan Pondok Pesantren Sa'adatuddaren Kota Jambi dalam pengelolaan program Pendidikan Kesetaraan Paket B masih terdapat pimpinan yang sering terlambat menyediakan alat-alat yang dibutuhkan oleh guru dalam bekerja. Untuk meningkatkan pelaksanaan kerja. Dalam hal ini Pimpinan Pondok Pesantren Sa'adatuddaren Kota Jambi melakukan pelatihan dan pendidikan supaya guru dapat bekerja secara optimal dalam menangani masalah pelaksanaan administrasi di Pondok Pesantren Sa'adatuddaren Kota Jambi.

Bukti komitmen pimpinan dalam pengelolaan program Pendidikan Kesetaraan Paket B dilakukan melalui penataan sistem manajemen serta mengadakan pembinaan kelembagaan yang memungkinkan terciptanya iklim kondusif dan pelayanan yang berkualitas dalam pengelolaan program Pendidikan Kesetaraan Paket B. Pembinaan kelembagaan merupakan suatu prospektif dalam merencanakan dan mengarahkan perubahan dalam suatu organisasi. Langkah pembinaan tersebut diperlukan oleh lembaga institusi dikarenakan tingkat kepuasan yang diterima oleh pengguna layanan tentunya akan terus berubah seiring dengan baiknya tingkat pendidikan. Dengan demikian dalam upaya meningkatkan pelaksanaan pelayanan diperlukan upaya yang sungguh-sungguh agar diharapkan dapat tercapai.

Kondisi tersebut dapat terimplementasikan dengan baik jika Pimpinan Pondok Pesantren Sa'adatuddaren Kota Jambi memiliki komitmen, dan motivasi dalam melaksanakan tugas pengelolaan program Pendidikan Kesetaraan Paket B. Dalam konteks ini setiap pegawai dituntut bekerja maksimal sesuai dengan potensi dan bidang tugas masing-masing. sekalipun demikian dalam posisinya sebagai salah satu pendukung tinggi rendahnya mutu pendidikan di daerah, pegawai pada dinas pendidikan dan kebudayaan dihadapkan pada berbagai masalah di mana salah satu persoalan yang terjadi adalah terkait dengan pelayanan administrasi yang belum berjalan maksimal. Hal ini dapat dilihat dari masih banyaknya keluhan yang disampaikan oleh masyarakat kepada aparatur pemerintah.

Sistem pelayanan merupakan suatu kegiatan atau urutan kegiatan pada suatu usaha yang dilakukan oleh seseorang atau kelompok orang maupun suatu instansi tertentu untuk memberikan bantuan dan kemudahan pada masyarakat yang mempunyai kepentingan dalam organisasi itu dalam rangka mencapai tujuan sesuai dengan aturan pokok dan tata cara yang telah ditetapkan. Pelayanan pada dasarnya melibatkan dua pihak yang saling berhubungan yaitu organisasi pemberi pelayanan di satu pihak dan masyarakat sebagai penerima pelayanan di pihak lainnya. 
Komitmen pimpinan Pondok Pesantren Sa'adatuddaren Kota Jambi berpusat pada administrasi dengan titik berat memberikan arah dan motivasi pencapaian tujuan baik jangka pendek maupun jangka panjang, memberi fasilitas pencapaian tujuan melalui pengalaman kerja yang memadai, membantu perkembangan aspekaspek pribadi seperti sikap, nilai-nilai dan penyesuaian diri. Demikianlah, dalam aktivitas administrasi, pimpinan tidak terbatas sebagai penyampai ilmu pengetahuan akan tetapi lebih dari itu, ia bertanggung jawab akan keseluruhan perkembangan kepribadian guru. Salah satu tugas itu adalah memberikan informasi tentang keadaan guru di Pondok Pesantren Sa'adatuddaren Kota Jambi tentang pembaharuan pekerjaan di unit pondok yang ada.

Para guru paket B di Pondok Pesantren Sa'adatuddaren Kota Jambi dengan segenap ketulusan hati memiliki kesadaran tinggi untuk melaksanakan tanggung jawab secara baik. Hasil penelusuran dan pengamatan penulis terhadap dokumen Pondok Pesantren Sa'adatuddaren Kota Jambi yang menyangkut aktivitas kerja membuktikan bahwa:

1. Sebagian besar guru telah melaksanakan tugas sesuai dengan waktu dan jam tugasnya. Adanya permasalahan individu ataupun tugas yang menyebabkan mereka tidak melaksanakan tugas sesuai dengan waktu yang telah ditentukan, telah dilakukan prosedur melalui izin Pimpinan Pondok Pesantren Sa'adatuddaren Kota Jambi dan diganti oleh guru piket pada hari tersebut.

2. Semua guru dengan baik melakukan tugas melalui tahapan-tahapan sesuai petunjuk pelaksanaan kerja yang meliputi: persiapan, perencanaan, pelaksanaan dan evaluasi.

3. Administrasi pondok telah dilakukan oleh guru dengan baik, terlihat dari dokumen Pondok Pesantren Sa'adatuddaren Kota Jambi

Keyakinan Pimpinan Pondok Pesantren Sa'adatuddaren Kota Jambi bahwa organisasinya dapat mencapai keunggulan diberbagai bidang ditempuh dengan menanamkan keyakinan kepada para guru bahwa Pondok Pesantren Sa'adatuddaren Kota Jambi dapat menghasilkan output yang unggul dengan mengutamakan proses kerja yang bagus, meski fasilitas kurang memadai. Penekanan untuk meningkatkan budaya kerja yang ikhlas buka semata-mata memandang imbalan material belaka.

Upaya yang dilakukan dalam mengatasi kurangnya koordinasi dengan instansi terkait yaitu pihak pengelola program Paket B di Pondok Pesantren Sa'adatuddaren Kota Jambi melakukan kerja sama dengan semua pihak dan segera melakukan koordinasi dengan Depertemen Pendidikan Kota Jambi. Melalui koordinasi ini pihak pengelola program Paket B di Pondok Pesantren Sa'adatuddaren Kota Jambi dapat mengikuti pelatihan, seminar dan lokakarya.

Pemimpin organisasi mempunyai tugas membantu bawahan dalam mengembangkan potensi yang mereka miliki dalam melaksanakan tugasnya sehari-hari. Manajemen kepemimpinan yang dilakukan meliputi perencanaan, organisasi, penggerakan dan pengawasan adalah bentuk tanggung jawab pimpinan suatu organisasi. Pemimpin harus mampu memberikan keseimbangan pada masing-masing tugasnya sebagai pemimpin dalam memanajemen bawahannya.

Konsep Islam mengatakan bahwa setiap orang adalah pemimpin dan akan bertanggung jawab atas kepemimpinannya. Kepemimpinan merupakan sebuah amanah dan kepercayaan yang diberikan oleh masyarakat ataupun sudah 
ditentukan oleh Tuhan, sehingga untuk menemukan jati diri seorang pemimpin bahwa keyakinan, keterampilan, kemauan dan hubungan sosial adalah sangat penting. Jadi inti kesuksesan suatu usaha atau lembaga publik pada dasarnya terletak pada kepemimpinan manajer atau pemimpinnya. Sekalipun organisasi itu tidak baik, peralatannya cukup, modal ada tetapi jika tidak dikelola oleh manajer atau pemimpin yang baik dalam memimpin, maka janganlah diharapkan akan berhasil, untuk itu suksesnya suatu badan usaha atau kemajuan suatu negeri dimulai oleh pemimpin yang berkualitas, enerjik, berkemauan keras, penuh gagasan yang realistik dan diikuti oleh penerusnya.

Pimpinan Pondok Pesantren Sa'adatuddaren Kota Jambi dalam hal ini sebagai manajer pendidikan sangat berperan di dalam perencanaan program pendidikan kesetaraan paket B di pondok sebagaimana diungkapkan oleh Pimpinan Pondok Pesantren Sa'adatuddaren Kota Jambi, bahwa peningkatan sistem informasi kinerja merupakan faktor yang sangat penting sebagai pendukung dalam penyampaian informasi kepada guru yang ada, oleh karena itu selaku pengelola Pondok Pesantren Sa'adatuddaren Kota Jambi selalu berusaha untuk merencanakan semaksimal mungkin untuk memenuhinya.

Pimpinan Pondok Pesantren Sa'adatuddaren Kota Jambi berfungsi sebagai pengendali terhadap jalannya usaha untuk meningkatkan kompetensi guru di Pondok Pesantren Sa'adatuddaren Kota Jambi. Meskipun seorang pemimpin selalu dihadapi banyak masalah untuk meningkatkan kompetensi guru seperti pelatihan guru. Perlu ditegakkan asumsi pentinya in-service education yaitu (a) semua personil Pondok Pesantren Sa'adatuddaren Kota Jambi memerlukan in-serve education sepanjang karirnya, (b) perkembangan praktik lapangan pendidikan meminta pertimbangan waktu dan hasil sistematis memerlukan pengembangan guru, (c) in-srevice education mempunyai dampak meningkatkan kualitas program Pondok Pesantren Sa'adatuddaren Kota Jambi dan profesionalitas personil; (d) perlunya motivasi belajar dimana mereka percaya ada kontrol dalam belajarnya; (e) lembaga Pondok Pesantren Sa'adatuddaren Kota Jambi sebagai unit belajar bertanggung jawab menyediakan sumber dan kebutuhan latihan guru Pondok Pesantren Sa'adatuddaren Kota Jambi. ${ }^{36}$

Dalam kepemimpinan Pondok Pesantren Sa'adatuddaren Kota Jambi, ia memiliki tugas utama sebagai pemimpin lembaga, tugas tersebut yakni mengelola situasi kegiatan organisasi pendidikan khususnya dalam bidang administrasi. Dalam melaksanakan tugas tersebut Pimpinan Pondok Pesantren Sa'adatuddaren Kota Jambi memiliki fungsi ganda yakni melaksanakan administrasi juga menjalankan fungsi supervisi terhadap pelaksanaannya. Melalui fungsi supervisor ini Pimpinan Pondok Pesantren Sa'adatuddaren Kota Jambi dapat berupaya untuk meningkatkan kinerjanya. Kegiatan pengawasan Pimpinan Pondok Pesantren Sa'adatuddaren Kota Jambi dalam keseluruhan proses pendidikan merupakan kegiatan yang integral terhadap keseluruhan proses kegiatan pendidikan lainnya.

\section{Penutup}

Berdasarkan hasil temuan penelitian di lapangan tentang komitmen pimpinan pondok dalam pengelolaan program Pendidikan Kesetaraan Paket B di Pondok

\footnotetext{
${ }^{36}$ Syaiful Sagala, Administrasi Pendidikan Kontemporer, (Bandung: Alfabeta, 2009), hlm. 244.
} 
Pesantren Sa'adatuddaren Kota Jambi belum optimal karena tidak menjadi skala prioritas pondok. Komitmen pimpinan pondok dalam pengelolaan program Pendidikan Kesetaraan Paket B di Pondok Pesantren Sa'adatuddaren Kota Jambi yang dilakukan dengan melakukan indentifikasi kebutuhan dan keinginan pimpinan pondok pesantren terhadap pengelolaan program Pendidikan Kesetaraan Paket B seperti berkomitmen menyelenggaraan program ini, keterlibatan pimpinan pondok pesantren dalam aktivitas-aktivitas kerja pengelolaan program Pendidikan Kesetaraan Paket B seperri merencanakan, melaksansakan dan mengawasai program tersebut dan loyalitas pimpinan pondok pesantren dalam mempertahankan kerjanya dalam pengelolaan program Pendidikan Kesetaraan Paket B. Pengelolaan program Pendidikan Kesetaraan Paket B di Pondok Pesantren Sa'adatuddaren Kota Jambi dimulai dengan menyusun rencana pengelolaan program Pendidikan Kesetaraan Paket B, kemudian menerima santri baru dalam melakukan pengembangan kecakapan hidupnya, membina guru agar bisa bekerja dalam pengelolaan program Pendidikan Kesetaraan Paket B, juga mengelola fasilitas yang membantu kerja program tersebut. Hambatan pimpinan Pondok Pesantren Sa'adatuddaren Kota Jambi dalam meningkatkan pengelolaan program Pendidikan Kesetaraan Paket B adalah keterbatasan pengalaman tutor/guru mengajar Paket B dan fasilitas yang terbatas. Pendukung pengelolaan program ini adalah visi yang sama antara pengelola dan guru dalam mengimplementasikan program Pendidikan Kesetaraan Paket B di pondok ini. 


\section{Bibliografi}

Abd. Kadim Masaong. Supervisi Pembelajaran dan Pengembangan Kapasitas Guru: Memberdayakan Pengawas Sebagai Gurunya Guru. Bandung: Alfabeta. 2012.

Abdul Rahmat. "Aktivitas Warga Belajar Paket B Dalam Kegiatan Pembelajaran di PKBM Taman Pendidikan Kelurahan Tapa, Kota Utara". Jurnal Pendidikan Non Formal (JPNF). Edisi 12 Tahun 2015.

Adamson, Dave and Richard Bromiley. Community Empowerment in Practice The Homestead 40 Water End York: Joseph Rowntree Foundation. 2008.

Eka Prihatin. Teori Administrasi Pendidikan. Bandung: Alfabeta. 2011.

Herry Nurdi. Living Islam. Jakarta: Lingkar Pena Kreativa. 2011.

Hilmi. Kinerja Perguruan Tinggi Agama Islam. Jakarta: Referensi. 2013.

Husaini Usman. Manajemen. Jakarta: Bumi Aksara. 2008.

Kasful Anwar US. Kepemimpinan Pesantren. Jambi Timur: Sulthan Thaha Press. 2011.

Lexy J. Moleong. Metodologi Penelitian Kualitatif. Bandung: Remaja Rosdakarya. 2013.

Miles, Matthew B. dan A. Michael Huberman, Analisis Data Kualitatif: Buku Sumber Tentang Metode-Metode Baru. Terj. Tjetjep Rohedi Rohidi. Jakarta: UI Press. 2007.

Minnah El Widdah, dkk. Kepemimpinan Berbasis Nilai dan Pengembangan Mutu Pondok. Bandung: Alfabeta. 2012.

Mujamil Qomar. Strategi Pendidikan Islam. Jakarta: Erlangga. 2013.

Mukhtar. Metode Praktis Penelitian Deskriptif Kualitatif. Jakarta: Referensi. 2013.

E. Mulyasa. Menjadi Kepala Sekolah Profesional. Bandung: Remaja Rosdakarya. 2006.

Rochgiyanti. "Pembelajaran Paket B di PKBM Barito Kota Banjarmasin", Artikel. FKIP Universitas Lambung Mangkurat, Banjarmasin.

Luluk Yuli Prasetyaningwati, Analisis Kebijakan Program Pengembangan Diri dalam Upaya Peningkatan Kecakapan Hidup Warga Belajar Paket B di Kota Malang, (Tesis), (Malang, PPs Univeritas Muhammadiyah Malang, 2009).

Rajo Bungsu. Pelaksanaan Kurikulum Paket A pada Suku Anak Dalam (SAD) di Desa Pelempang Kecamatan Mestong Kabupaten Muaro Jambi. (Tesis). (Jambi: Pascasarjana IAIN STS Jambi, 2011).

Sudarwan Danim. Kinerja Staf dan Organisasi. Bandung: Pustaka Setia. 2008.

Sugiyono. Metode Penelitian Pendidikan: Pendekatan Kuantitatif, Kualitatif dan $R$ \&D. Bandung: Alfabeta, 2007.

Suharno, Manajemen Pembelajaran Kejar Paket C (Setara Sma) Studi Multi Kasus Di PKBM Sidoharjo Dan PKBM Slogohimo Kabupaten Wonogiri, (Tesis), (Surakarta, PPs Univeritas Muhammadiyah Surakarta, 2005).

Suharsimi Arikunto. Prosedur Penelitian. Jakarta: Rineka Cipta. 2006.

Sutrisno Hadi. Metodologi Riset. Yogyakarta: Pustaka Pelajar. 2015.

Syaiful Sagala, Administrasi Pendidikan Kontemporer, Bandung: Alfabeta, 2009. 
Wahjosumidjo. Kepemimpinan Kepala Sekolah. Jakarta: RajaGrafindo Persada. 2007.

Wells, Denise Lindsey. Strategic Management for Senior Leaders: A Handbook for Implementation Arlington, Virginia: Department of the Navy Total Quality Leadership Office.

Wibowo. Perilaku dalam Organisasi. Jakarta: RajaGrafindo. 2013. 